\title{
Kütahyalı Firâkî Üzerine Yapılan Çalışmalar ve Yeni Şiirleri Üzerine Düşünceler
}

\author{
Mehmet ALTINOVA ${ }^{l}$
}

\section{Öz}

Asıl adı Abdurrahman Çelebi olan Firâkî, XVI. yüzyılda kendine özgü tarzı ve sade diliyle adından sıkça söz ettiren şairlerden biridir. Tezkirelerde adı zikredilen Firâkî, Kütahya'da bulunan şehzade Bayezid'den câize almaya hak kazanmıştır. Eski Anadolu Türkçesine ait bazı kelimeleri şiirlerinde başarılı bir şekilde kullanan Firâkî’nin şiirleri kendi dönemi içerisinde yer alan çok önemli şairler tarafindan tanzir edilmiş, bu bağlamda Firâkî, geniş bir edebiyat çevresinde bulunmayı başarmıștır. $\mathrm{Bu}$ zamana kadar yapılan çalışmalar neticesinde dîvânına rastlanılmadıysa da mecmualardaki şiirlerinin derlenip toparlanması, edebiyat tarihi açısından son derece önemlidir. Şairin yurt içindeki kütüphanelerde bulunan şiirler, bazı araştırmacılar tarafından yayımlanmıştır. Fakat bu yayımlar, yurt içindeki mecmualarla sınırlı kalmış, yurt dışındaki mecmualar ihmal edilmiştir. Bu sebeple şiirlerinin tamamı gün yüzüne çıkartılamamıştır. Bu çalışmada Firâkî hakkında bilinenlerden kısaca bahsedildikten sonra Firâkî üzerine yapılan çalışmalara değinilecek ve ardından çeşitli mecmualarda bulunan üçü gazel biri musammat olmak üzere daha önce Firâkî’nin yayımlanmamış dört şiiri nüshalarıyla birlikte tanıtılacaktır. Ayrıca daha önce yayımlanmamış Pervâne Bey mecmûasından on dört, Mucmâ'u'n-nezâir'den ise bir gazele çalışmada yer verilecektir. Buna ilâve olarak sözü edilen şiirler üzerinden önceki şiirleriyle bağlantılar kurularak Firâkî'nin edebî şahsiyeti hakkında birtakım tespitler yapılacaktır.

Anahtar Kelimeler: Firâkî, XVI. yüzyıl şairleri, Abdurrahman, Firâkî-i Vâiz, Germiyan.

\section{Studies About Firaki of Kutahya and Thoughts On New Poems}

\begin{abstract}
Firaki, whose real name is Abdurrahman Celebi, is one of the poets who freguently mentioned his name in his 16th century with his unigue style and simple language. Firaki, whose name is freguently mentioned in the tezkires, is entitled to receive some seyhzade, sons of sultan, in Kutahya. He used some of the ancient Anatolian Turkic words in his poems successfully. Firaki's poems were recognized by very important poets in his period, and in this context Firaki succeeded in obtaining a broad literature environment. Although the dîvân, the books of ottomants poetry, was not found after the works done until this time, the compilation of the poems in the magazines is very important in terms of literary history. The poems in the local libraries are published by some researchers. However, these publications have ignored overseas resources that are limited to domestic media. For this reason all of his poems have not been able to find. In this study, the works about Firaki will be mentioned briefly, then the works on Firaki will be mentioned and then the three poems which are not published previously will be introduced together with their original copies. At the same time fourteen poetry had given from Pervâne Bey's magazine, called as Perane Bey mecmuası and one porty had given from Mecmuâ'u'n-nezair that owner this magazine Edirneli Nazmi. In addition to this, the poems mentioned above will be established in connection with the previous poems and some determinations about the literary personality of Firaki will be made.
\end{abstract}

Key words: Firaki, 16th Centry poetrys, Abdurrahman, Firaki-i Vaiz, Germiyan.

${ }^{1}$ Yüksek Lisans Öğrencisi, Kütahya Dumlupınar Üniversitesi, Türk Dili ve Edebiyatı Bölümü, mehmetaltinova@hotmail.com 


\section{Kütahyalı Firâkî Hakkında Bilinenler}

Germiyan sahasının önemli şairlerinden biri olarak bilinen Firâkî, XVI. yüzyılda yaşamıştır. XVI. yüzyılda yaşamış Latifî, Âşı̧k Çelebi, Hasan Çelebi, Beyânî, Ahdî, Gelibolulu Mustafa Âlî, Taşköprüzâde ile XVII. yüzyıl tezkire sahiplerinden Riyâzî ve Fâ’izî’nin eserlerinde Firâkî Çelebi'nin adı geçmektedir. Türk Edebiyatı İsimler Sözlüğü projesinde Mehmet Fatih Köksal tarafından yazılan Firâkî maddesinde şairin hayatına dair şu bilgilere yer verilir:

“Asıl adı Abdurrahman'dır. Acem diyarından gelip Kütahya'ya yerleşen bir ailenin çocuğu olarak Kütahya'da doğdu. Kanunî devri şairlerinden olup Zeyniye tarikatinden bir şeyhin oğludur. İyi bir eğitim gören Firâkî, medrese öğrenimini tamamlayacă̆ı sırada babasının isteği üzerine feragat ederek memleketine döndü ve vaizliğe başladı. Bir aralık içki müptelası olduysa da sonradan tasavvufa yönelerek Abdülmümin Zaviyesi'nde çile çıkardı. Sultan Bayezid Kütahya'da şehzadeyken vaazını çok beğenmesi üzerine ona caize verdi. Ölüm tarihi hususunda kaynaklar ihtilaflıdır: 980/1572/73); 983/1575/76, 988/1580/81, 990/1582/83 ve 993/1585 olarak beş farkl tarih gösterilmektedir." (Köksal 2013). ${ }^{2}$

Beyânî’ye göre vaaz ve ögüt yolunu seçen Firâkî, dindar bir kişidir. Şehzade Bayezid, Kütahya'dayken onun vaazını pek çok kez dinlemiştir. Bunun üzerine Firâkî, pek çok kez şehzadeden caize almıştır (Kutluk 1997: 64)3. Bunun yanı sıra “Evliya Çelebi, Firâkî’nin amcasının oğlu olduğunu ve İstanbul'a göç ettiklerinde evlerini Firâkî'ye bıraktıklarını söylemektedir. Her iki sanatçının da Çelebi olması bu düşünceyi doğrular niteliklerden biridir. (...) Firâkî, dinî ilimler tahsil etmiş bir aileden geldiği ve medrese tahsilini Kütahya'da tamamladı̆̆ için Firâkî-i Vâiz olarak tanınmıştır." (Güler 2016: 87) Firâkî’nin, Bursalı Lâmiî Çelebi'nin musahibi olduğu da hakkında bilinenler arasındadir. $^{4}$

Eserleri arasında Hüseyin Vâiz-i Kâşifî’nin siyasetnâme özelliği taşıyan Farsça eserinin Türkçe tercümesi olan Terceme-i Ahlâk-ı Muhsinî, birtakım dinî soruları sorup cevaplama tekniğini kullanarak telif ettiği Kırk Sûâl adlı eseri ile Hüsrev ü Şîrîn mesnevîsi vardır. Bununla birlikte Yavuz Sultan Selim ve Kanûnî Sultan Süleyman'ın gazalarını konu edinen, Selîm-nâme ve Süleyman-nâme türünden sayılabilecek beş bin beyitten oluşan Sa'âdet-nâme adlı manzum tarih kitabı da bulunmaktadır. Amcası Evliya Çelebi, Seyahatnâme'de Firâkî’nin dîvânının haricinde kırk üç telif eserinin bulunduğunu, dört dili de fasih ve etkili olarak kullanabildiğini söylemektedir (Dağlı vd. 2005: 18). Firâkî, gerek Sa 'âdetnâme gibi manzum gerekse Kırk Su'al gibi mensur eserler kaleme alarak hünerini göstermiştir. Şu ana

\footnotetext{
${ }^{2}$ Köksal bu maddeyi 2013 yılında kaleme almıştır ama Kadir Güler'in 2010 yılında yayımlanan kitabını ve makalesini görmemiştir.

${ }^{3}$ Kütahya kasabasındandır. Va'z ve öğ̈̈t yolunu seçmiş, dindar bir kişidir. Şehzâde Sultan Bâyezid Kütahya'da iken onun va'zinde birçok kez hazır bulunmuştu. Bunu firsat bilen Firâkî, ayağa kalkıp yüksek sesle şehzâdeye dua ederek sayısız câize almıştır Kutluk 1997: 64.

${ }^{4}$ Hayatı hakkında ayrıca bilgi için bkz. Güler 2004: 53; Güler 2010: 232-260; Güler 2017: 92-97.
} 
kadar yapılan araştırmalar neticesinde şairin manzum eserleri ön plandadır. ${ }^{5}$ Evliya Çelebi’nin belirttiği kırk üç eser araştırmacılar tarafından ortaya çıkarıldığında Firâkî’nin edebî yönü hakkında yeni şeyler söylememize olanak sağlayacaktır.

Mecmualarda Firâkî'ye ait tespit edilen bir kaside ve pek çok gazel bulunmasına rağmen dîvânı henüz bulunamamıştır. Şairin eserlerine bakıldığında şiir konusunda son derece yetkin, edebiyat konularına vâkıf olduğu görülmektedir. Bu durum Evliya Çelebi'nin Seyehatnâme adlı eserinde geçen şairin dîvânı olduğu bilgisini doğrular niteliktedir. Gazel, murabba, muhammes, matla gibi çeşitli nazım şekilleriyle şiirler kaleme alan Firâkî, sade Türkçesi ile Anadolu'da yaşayan kan, kanı, şol, ana, ata gibi kelimeleri şiirlerine aktarmayı bilmiştir. Firâkî’nin şiirlerinde tespit ettiğimiz arkaik kelimelerden hareketle şairin Arapça ve Farsça'nın etkisinde fazla kalmayıp Türkçe anlaşııır şiirler yazdığını söylemek mümkündür.

\section{Hakkında Yapılan Çalışmalar}

Kadir Güler'in makalesinden öğrendiğimize göre (Güler 2010b) Kütahyalı Firâkî üzerine ilk çalışmaları Kütahya'nın entelektüel simalarından arşivci ve kütüphaneci Mustafa Hakkı Yeşil yapmıştır. Yeşil, İstanbul'daki kütüphanelerde görevli olduğu zamanlarda Firâkî’ye ait şiirleri çeşitli mecmualardan derleyerek bir cönkte toplamıştır. Bu şiirler daha sonra Güler tarafından yayımlanmıştır. ${ }^{6}$

Hamza Güner, Kütahya'nın şairlerini anlattığı eserinde Firâkî Abdurrahman Çelebî’ye de yer vermiştir. Güner, sözü edilen eserinde Firâkî Çelebi’ye ait Ahlâk-ı Muhsîn ile Kırk Sual adlı kitaplarından kısaca bahseder (Güner 1967: 143-144).

Ersen Ersoy, XVI. Yüzyıl Kaynaklarına Göre Kütahyalı Şairler ve Kütahya'da Edebî Muhît adlı yüksek lisans tezinde Firâkî hakkında birtakım bilgilere ve Latîfî ile Âşıı Çelebi'nin tezkirelerinde geçen şiirlere yer vermiştir (Ersoy 2003).

Firâkî’nin eserlerinin bir kısmı Kadir Güler danışmanlığında yapılan tezlerde yeni harflere aktarılıp incelenmiştir. Bu çalışmalar içerisinde Kırk Suâl, Yücel Önen tarafından çalışılmış (Önen 2009); aynı zamanda kendisine ait bir diğer eser Terceme-i Ahlâk-ı Muhsinî, Mehmet Avçin tarafindan yeni harflere aktarılmış ve incelenmiştir (Avçin 2011). Halit Çelik tarafından yüksek lisans tezi olarak hazırlanan Sa'âdetnâme adlı manzum tarih kitabı çeviri yazı şeklinde çalışılmıştır (Çelik 2011). Çalışma Şaban Er tarafından yayımlanmıştır (Er 2013). Şaban Er aynı zamanda Süleymaniye Yazma Eserler Kütüphanesi'nde bulunan Firâkî'ye ait Sûret-nâme adlı birkaç varaklık risalesini de sözü edilen çalışmasında yer vermiştir.

\footnotetext{
${ }^{5}$ Taramalarımıza göre Firâkî’nin bulunan tek mensur eseri Kırk Su'al'dir. Eser hakkındaki bilgi ve yapılan çalışma makale içerisinde geçmektedir.

${ }^{6}$ Ayrıntılı bilgi için bkz. Güler, 2010b: 1037-1066.
} 
Bunun dışında Firâkî üzerine yapılan çalışmalar çeşitli dergilerde yayımlanmıştır. Bunlar arasında dikkate değer olanlardan biri Halil Ersoylu'nun Türk Dili Araştırmaları Yıllığı Belleten'de 1995 'te yayımladığı "Kaside-i Kalem” adlı makaledir. Ersoylu, sözü edilen makalede Firâkî hakkında kısaca bilgi vermiş, klâsik edebiyatta kalemle ilgili yazılan şiirlerden bahsedip Firâkî’ye ait 35 beyitlik bir kasideyi tanıtmıştır. Ardından kasidede geçen kelimelerin sözlük anlamlarını verip kasidenin nüshasını çalışmasına eklemiştir (Ersoylu 1995). Bu makalenin yayımlanmasının ardından Mehmet Kalpaklı, Ersoylu'nun makalesindeki okuma hatalarını tespit ederek metin üzerine eleştirel bir okuma gerçekleştirmiştir (Kalpaklı 1997).

Mehmet Fatih Köksal tarafından Türk Edebiyatı İsimler Sözlüğü projesinde şairin biyografisi işlenmiştir (Köksal 2013). Merve Mutlu, Süleymaniye Kütüphanesi Nuri Arlasez koleksiyonunda bulunan bir mecmua içerisinde tekrar eden bir şiirle birlikte Firâkî’ye ait yedi şiir tespit etmiş ve sözü edilen şiirler bilim dünyasına tanıtılmıştır (Mutlu 2014).

Tespit edildiği kadarıyla mezkûr şair hakkındaki son çalışma Asuman Bayram tarafından yapılmıştır. Bayram, çalışmasında tek nüshası Macar Bilimler Akademisinde bulunan Firâkî’ye ait Hüsrev ü Şîrîn mesnevîsini çeviri yazı şeklinde Kültür Bakanlığı e-kitap projesi kapsamında yayımlamıştır (Bayram 2017a). Bayram, ayrıca Firâkî’nin sözü edilen mesnevîsinin bağlamlı dizin ve işlevsel sözlüğünü doktora tezi olarak hazırlamıştır (Bayram 2017b). Kütahyalı Firâkî’nin yayımlanan şiirlerinin bağlamlı dizin ve işlevsel sözlüğü tarafımızdan hazırlanmaktadır.

Araştırmalara göre, Firâkî’nin şiirleri Âhî, Hasbî, Karârî, Me’âlî, Muhibbî, Rahmî, Sa’dî, Şâhî, Selimî tarafından tanzir edilmiştir (Gıynaş 2017: 15). Firâkî ise Ahmed Paşa (3), Enverî (1), Hayretî (1), Kemal Paşa-zâde (2), Kıvâmî (1), Mesihî, Necâtî (1), Nizâmî (1), Usûlî (1), Ulvî (1), Zâtî (1) ve Cem Sultan'a (1) nazireler yazmıştır. ${ }^{7}$ Firâkî'nin Pervane Bey mecmuasında üç, Mecma 'u'n-Nezâ 'ir'de ise iki gazeli bulunmaktadır (Köksal 2017) ${ }^{8}$. Bu bilgilerden hareketle mecmuaların şiirleri tespit etmedeki önemi çok açık bir şekilde anlaşılmaktadır. Öte yandan Firâkî’nin şiirlerini tanzir eden şairlere bakıldığında dönemin önemli şairleri olduğu görülür. $\mathrm{Bu}$ da onun şiirdeki maharetini gösteren önemli bir delil niteliğindedir.

\section{Yeni Şiirlerin Tanıtılması}

Çalışmada yer verilen gazellerden biri Paris National Bibliothègue Turk 302 numarada kayıtlı mecmuada yer almaktadır. Mecmuanın içerisinde Revânî, Muhibbî, Zâtî, Âhî, Necâtî gibi pek çok şairin şiirleriyle birlikte Firâkî'ye ait beş beyitlik gazel de bulunmaktadır. Firâkî'nin şiiri mecmuanın 226'ncı varağında olup bu varakta şiirle birlikte çizilmiş bir vazo resmi de yer alır.

\footnotetext{
${ }^{7}$ Firâkî Çelebi'nin Pervane Bey mecmûası içinde yer alan şiirlerine çalışma içerisinde yer verilmiştir.

${ }^{8}$ Mecmûa'u'n-Nezâir'de ise Firâkî Çelebi'nin nazire yazmış olduğu şiirler bulunmaktadır. Sözü edilen şiirlerden birinde -uñ (2689) redifi bulunurken diğerinin redifi olmayıp kafiyesi -ān (3423)'dır. Bunlardan -uñ redifli gazeli Türk Edebiyatı İsimler Sözlüğü projesinin Firâkî maddesinde geçtiği için burada tekrar almaya gerek duymadık.
} 
Firâkî’ye ait bir başka şiir de Paris National Bibliothègue Turk 288 numarada kayıtlı mecmuada yer almaktadır. İçerisinde Muhibbi, Ulvî, Bâkî gibi usta şairlerin şiirlerinin de yer aldığı mecmuada Firâkî’ye ait beş bentlik bir mütekerrir murabba bulunmaktadır.

Çalışmada yer verdiğimiz üçüncü bir şiir de gazel nazım şekliyle kaleme alınmıştır. Beş beyitten oluşan bu gazelin nüshası İstanbul Süleymaniye Yazma Eserler Kütüphanesi'nde Tercüman Gazetesi Kütüphanesi arşivi Y-110 arşiv numarasıyla kayıtlıdır. XIX. yüzyıla ait olduğunu tahmin ettiğimiz Mecmû'a-i Eş'âr $r^{9}$ isimli bu eserin içerisinde XVI. yüzyıl şairlerinden Bâkî, Fuzûlî Nâbî, Hüdâyî, Râgıb Paşa, Nâdirî, Rahmî, Ahmed Paşa gibi çok ünlü şairlerin yanında ismi çok duyulmamış şairlerin şiirleri de bulunmaktadır.

Firâkî’ye ait bir başka gazel Süleymaniye Kütüphanesi, Ali Nihat Tarlan koleksiyonunda 59/1 arşiv numarasına kayıtlıdır.

Süleymaniye Kütüphanesindeki taramalar sonucunda şaire ait bir terci-i bende rastlanıldı. Nuruosmaniye koleksiyonu 04959-004 arşiv numarasına kayıtlı bu mecmuanın sayfa kenarında bulunan bu terci-i bend müstensihin hatası sonucu terkib-i bend olarak başlık yazıldığı ve doğal olarak kütüphane kayıtlarına da bu şekilde geçtiği fark edildi. Bu şiirin daha önce araştırmacılar tarafından yayımlanıp yayımlanmadığını araştırırken Kadir Güler'in sözü edilen makalesinde (Güler 2010b) yayımlandığı görüldü. Tarafımızdan tespit edilen terci-i bend ile Kadir Güler'in şahsî kütüphanesinde bulunan, Mustafa Hakkı Yeşil'in İstanbul'daki kütüphanelerde görevli olduğu yıllarda mecmualardan derlediği şiirleri ihtiva eden cönkteki terci-i bend arasında bazı nüsha farkları olmasına karşın yayımlamaya gerek duyulmadı. Sadece Güler'in sözü edilen cönkteki bir kelimenin silik çıkmasından dolayı okunamayan dizeyi tarafımızdan tespit edilen nüshadan tamamlamayı uygun gördük. ${ }^{10}$

Bu şiirlerin dışında Pervâne Bey mecmûasında yer alan on dört şiir ile Mecmûa'u'n-nezâir'de yer alan bir gazele çalışmada yer verilmiştir. Mecmûa'u'n-nezâir'de yer alan diğer gazel Türk Edebiyatı İsimler Sözlüğ̈̈'nün Firâkî maddesinde Firâkî’nin şiirlerine örnek olarak verildiğinden burada tekrar yer vermeyi uygun görmedik.

Yurt dışındaki kütüphanelerin katalogları tarandığında Firâkî’ye ait şiirlerin daha fazla olduğu görülmektedir. ${ }^{11} \mathrm{Bu}$ eserlere ulaşıldığında sayısı daha da artacak olan Firâkî’ye ait şiirlerin şimdilik tespit ettiğimiz ve ulaşabildiğimiz şiirleri aşağıdaki şekildedir:

\footnotetext{
9 Sözüne edilen mecmûanın içerisinde XIX. yüzyılda yaşamış Kıbrıs şairlerinden Hilmî’nin de şiirleri yer almaktadır. Mecmûanın XIX. yüzyıla ait olabileceği söylenebilir.

${ }^{10}$ Sözü edilen dize şu şekildedir;

Âlem-i kesrete zinhār mukayyed olma

Gör ne hoş vahdet imiş mülk-i firāk-1 1tlak bkz. Ek: 6 .

${ }^{11}$ Yazma eserlerin genel ağının taranması sonucunda Firâkî’ye ait şiirlerin bilhassa Ankara Milli Kütüphanede bulunan mecmualarda olduğu tespit edilmiştir. Bunun yanında Mısır Milli Kütüphanesi Türkçe El Yazmaları, Fransa Milli Kütüphanesi Türkçe El Yazmaları, Berlin Kütüphanesi, Avusturya Dükalık Kütüphanesi Gotha
} 


\section{Gazel I ${ }^{12}$ \\ Mefâ'îlün/ Mefâ'îlün/ Mefâ'îlün/ Mefâ'îlün \\ Firākī Çelebī Fermāyed}

Lebüñ şevḳına ḳanı şol yaşum ḳan itdügüm demler

Cihānı ser-te-ser la '1-i bedehşsān itdügüm demler

Yaḳanı sīnemi şol ḳanlu ḳanlu oṭagaalarla

Ḳızıl güller açılmış yer pür gülistān itdügüm demler

Niçün 'ahdüñe țurmazsın meger kim geçdü ${ }^{13}$ yāduñdan

Behey zāalim senüñle 'ahd u peymān itdügüm demler

Yeñi yaḳası yoḳ tọnlar giyerdi eski 'āşıḳlar

Senüñ 'işkuñda ben çāk-i girībān itdügüm demler

Dahı bilmezdi ‘ ālem neydügin feryād u fỉgānı

Firāḳ̄ ney gibi feryād [u] efḡān itdigüm demler

\section{Li-muharrir el-Hुalīlü'l Hualīl}

\section{Gazel II ${ }^{14}$ \\ Fâ'ilâtün/ Fâ'ilâtün/ Fâ'ilâtün/ Fâ'ilün}

\section{Firāḳ̄i}

Dōstum el baġlayup dīvāna geldüm yüz sürüp

Bende-i bī-çāreyem fermāna geldüm yüz sürüp

Sevdi göñlüm göreli devletlü sulțānum seni

'Āş1ḳ-1 dil-ḩasteñem dermāna geldüm yüz sürüp

Gice gündüz iñledüm diñmez fig̣ānum bir nefes

Hecr elünden dād içün sultạna geldüm yüz sürüp

Bülbül-i gūyā menem gülzār-1 hüsnüñde senüñ

Gül yüzün ḳarşusına efḡāna geldüm yüz sürüp

Yoḳ dime billâh luṭfuñdan Firāḳī bendeñe

Almag̉a bir būseñi biñ cāne geldim yüz sürüp

\footnotetext{
Koleksiyonu Türkçe El Yazmaları bölümü, İsviçre Zürih Boşnak Enstitüsü Türkçe El Yazmaları bölümünde Firâkî’ye ait şiirlerin yer aldığı eserler bulunmaktaysa da bunlara maalesef ulaşamadık. Buradaki şiirlere ulaşmak için sözü edilen kütüphanelerle görüşmekteyiz.

${ }^{12}$ Bkz. Ek 1.

${ }^{13}$ Metinde geydi şeklindedir.

${ }^{14}$ Bkz. Ek 3
} 


\section{Gazel III ${ }^{15}$}

\section{Fâ'ilâtün/ Fâ'ilâtün/ Fâ'ilâtün/ Fâ'ilün}

\section{Firākī Fermāyed}

Țaşdı göñlüm āh kim 'ummān-1 bī-hemtā gibi

Aşdı başumdan gözüm yaşı deñiz deryā gibi

Yaḳdı yandırdı beni sevdā-yı ḥāl-i ḩadd-i yār

Lālenüñ ṭag̉larda bag̀rın țag̉layan sevdā gibi

Dil meger tôlāb-1 gamdır kim dükenmez nālesi

Yā giriftār-1 ḳafesdir ${ }^{16}$ bülbül-i gūyā gibi

Ben yetīme bilmezem yā Rab ne dermān ola kim

Derd anası atası oldum Ebu'd-Derdā ${ }^{17}$ gibi

Ey Firāḳ̄i bir gözi hūn̄i nigārum var benim

Günde biñ bir 'āşıḳıñ kanın içer dünyā gibi

\section{Gazel IV}

Mefâ'îlün/ Mefâ'îlün/ Fe'ûlün

Nazīre-i Firāk̄i -i Vā'iz

Çerāguuñ hadd-i yāra nisbeti var

'Aceb şevḳi 'aceb germiyyeti var

Oḳundı mūm ile pervāneler hep

Meger şem üñ gice cem 'iyyeti var

Diler dil yoḳlug ile vasl-i yarı

Faḳī ammā Hịīà'a niyyeti var

Ne țurursın yitiş dil-dāra ey dil

Ki 'ömr-i nāzenīnüñ sür'ati var

Firāḳ̄ tabl-i sīneñ dest-i rıhlet

Dögiser bir gün ammā nevbeti var (Gınaş 2017: 646)

\section{Gazel V}

Fâ'ilâtün/ Fâ'ilâtün/ Fâ'ilâtün/ Fâ'ilün

Naẓ̄ire-i Firākī -i Vā'iz

Șubḥ dem gül-zāra gel nūr-i cemal-i yarı gör

Çihre-i gülden tecelli eyleyen dīdārı gör

Dil uzadup bülbül-i pür-zāra söyler ġonçeler

Hāār ü hasdan nāle vü feryādı kes gül-zārı gör

Șūret-i ādemde ma nā gösteren mir'āta bak

Gör neler seyr itdürür āyīne-i ruhsārı gör

\footnotetext{
${ }^{15}$ Bkz. Ek 4 ve Ek 5.

${ }^{16}$ Metinde ḳafaș biçiminde yazılmıştır.

${ }^{17}$ Ebu'd-Derda, Kur'an muallimliği ve Dımaşk kadılığı yapan sahabîlerden biridir. Beyitteki bağlamda Ebu'dDerda'nın kadı oluşuna işaret vardır.
} 
Eyleme her hāa-i pāy olan gedaya kem nazar

Zerreye pertev șalan ol mihr-i pür-envārı gör

Keşf-i rāz itmek murāduñsa dehān-i yardan

Vākıf-i sırr ol Firāḳī maḩzen-i esrārı gör (Gıynaş 2017: 1031)

\section{Gazel VI}

Mef'ûlü/Fa'ilâtün /Mef'ûlü / Fa'ilâtün

Naẓire-i Firākēi -i Vā'iz

Kaddüñ nihāl-i cāndur bāg̀-i cinānda bitmez

Dil gülşeninde diksem țañ mı yabānda bitmez

Zülfüñ miŝali sünbül Rūm içre ḳopmaz ey gül

Ḩālüñ gibi ḳaranfül Hindūstān'da bitmez

Başumdan odlu dāġlar göz oldı ḳanlar ag̉lar

Bir gülmedük başum var oñmaz cihanda bitmez

Cismümde 'aḳs-i hatțuñ bir sebzezāra beñzer

Sebze egerçi rūy-i āb-i revānda bitmez

Bostāncıbaşı og̉lın sevdüm diyü Firāḳ̄

Hey cāna başa ḳıyma cān bostanda bitmez (Gıynaş 2017: 1210)

\section{Gazel VII}

Fâ'ilâtün/ Fâ'ilâtün/ Fâ'ilâtün/Fâ'ilün

Naẓīe-i Firākī -i Vā'iz

Var midur bir dīde kim derdüñle ol giryān degül

Kanı bir dil tāb-i hüünüñ şevḳile sūzān degül

'Āşı ḳa cān terkin urmaḳ emr-i āsāndur velī

Ayru düşmek sevgülü cānāndan āsān degül

Kaṣd-i kurbān itse gamzeñ hançeri ḳașșābvār

'îd-i hüsnüñ görmeğe kimdür bugün ḳurbān degül

Ḩū idindi bī-güneh 'uşşāḳ göñlin yıḳmag̉a

Nice diyem k'ol melek yüzlü insān degül

Kondi sulțān-i hayālüñ çün Firāḳī göñline

Devletüñde dimezem şāhā ki ābādān degül (Gıynaş 2017: 1722-1723)

\section{Gazel VIII}

Mefâ'îlün/Mefâ'îlün/Fe'ûlün

Naẓ̂re-i Firākī -i Vā'iz

Gel e bir dem ḳadem baṣ bezme sāḳ̂̄

Degüldür çün bu demler bize bāḳ̄

'Ömr peymānesi țolmazdan evvel

Ṭolu ṣun içelüm cām-i revāḳı

Ḩațuñ bir gün cemālüñ șafḥasında

Yazar el- 'ömrü fānī hatṭt bāḳ̄ 
Geçer devr-i ḥasenüñ țañ mı ey māh

Budur devr-i zamānuñ ittifāḳı

Harīị olma Firāḳī her viṣāle

Ki vardur her viṣālüñ bir firāḳı (Gıynaş 2017: 2650)

\section{Gazel IX}

Fâ'ilâtün/ Fâ'ilâtün/ Fâ'ilâtün/Fâ'ilün

Naẓīe-i Firāk̄̄

Şöyle sevdüm ey perī-peyker seni cānum gibi

İsterem sīnemde pinhān idem īmānum gibi

Kūyuña vardukça 'izzetlerle istiḳbāl idüp

İtlerüñ ḳarşu çıḳarlar baña yārānum gibi

Gögsüñ açsañ germ olup meclisde ey gül gonçesi

Çāk çāk olmaz yaḳa ķalmaz girībānum gibi

Būsuñ almış āh kim bezm-i maḥabbetde ḥasūd

Sāgaruñ ḩod oldı bag̉n çeşm-i giryānum gibi

Ey Firāḳ̄ gözlerüm yaşını seyl-āb eyleyen

Gayrlarla șalınan serv-i ḩırāmānum gibi (Gıynaş 2017: 2686)

\section{Gazel X}

\section{Fâ'ilâtün/ Fâ'ilâtün/ Fâ'ilâtün/Fâ'ilün}

\section{Naz̄īe-i Firākī}

Kạșr-i 'așruñ çār erkānın ne deñlü țavra țut

Dār-i dünyānuñ çü bünyān-1 ke-beyti'l- 'ankebūt

Çı̣̣ bu zuulmetden ḥayāt-i cāvidānī ḳıl țaleb

Her zamān olmaz çü ḩalvetgāh-i Yūnus baṭn-i ḥūt

Lāle-veş od üzredür billāhi bāg u rāg̣da

Seyr-i ṣahrā-yi fenādan ṣu gibi göñlün ṣovut

Şerbet-i cām-i eceldür 'ādem āhir ġ̀dā

Şehlere her vaḳt olur șanma kebūter-beççe kūt

Ey Firāḳī ne gedā ḳalur bu menzilde ne şāh

Kimse bāḳī ķalmaz illā kim o Ḥayy-i lā-yemūt (Gıynaş 2017: 432)

\section{Gazel XI}

\section{Fâ'ilâtün/ Fâ'ilâtün/ Fâ'ilâtün/Fâ'ilün}

\section{Ve lehu kezāā}

Gün gibi hercāyīlerden șubḥ-dem göñlün șovut

Menzülüñde her meh-i nā-mihr ahşamladi țut

Șaç saḳal ag̉ardı ḳıl ışk-i mecāzīden güzerer

Göz göre bir penbezāra urma hey dīvāne ot

Her ża īf ü zāra alçaḳ baḳma nā-çīz iken

Perde-i ġār-i Muhammed oldı țar-i 'ankebūt 
Sākī-i devrān ecel cāmın șunar çün kim saña

Yüz çevürme göz yumup ey dil ne zehr olursa yut

Ḩaylī bīhūde kelām itdüñ Firāḳi vaḳtidür

Ṭut dilüñ şimden gerü ur aġzuña mühr-i sükūt (Gıynaş 2017: 432-433)

\section{Gazel XII}

Fe'ilâtün/ Fe'ilâtün/ Fe'ilâtün/Fe'ilün

Naẓīe-i Firākī -i Vā'iz Kütahiyyevī

Virdi fetvā haț-i müşgīnüñ ile noḳta-i hāa

Ki ḥarāmī gözüñe hūô-1 muhịib ola ḥelāl

Meh ü hurşīid düşüp yüz sürer ey şāh-i cemāl

Kanda kim na' l-i semendüñ göriñe şekl-i hilāl

Gül ‘izāruñla nice ola ber-ā-ber kim aña

Meh virür reng ü mehe mihr-i ruhuñ nūr-i cemāl

Leblerüñ yādına ş'ol nesne ki cān itdi revān

Tā ebed hāà-i mezārından aḳar āb-i zülāl

Rūḥ taṣvīr ide naḳḳ̄ṣ eger ey büt-i Çīn

Șūretüñ naḳşına bag̉larsa żamīrinde ḩayāl

Nūş-i meyde eger olmazsa ferah-bahş lebüñ

Dil-i gam-gīn idimez bāde ile def'

Daḩı şem 'ine Firāḳi gibi pervāne olup

Ṭāyir-i sidre-nişīn yaḳsa 'aceb mi per ü bal (Gıynaş 2017: 1700-1701)

\section{Gazel XIII}

Fâ'ilâtün/ Fâ'ilâtün/ Fâ'ilâtün/Fâ'ilün

\section{Naz̄īre-i Firākī}

Kūy-i dil-berden ıraġam 'andelībem kim hemān

Gülsitānından cüdā düşmiş fig̀ān eyler fig̀ān

Dīne ḳaṣdı var ruhuñ devrinde ş’ol bir kāfirüñ

El-emān ol fitne-i devr-i kamerden el-emān

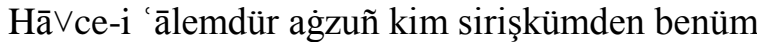

Gönderür her dem 'adem şehrine yüz biñ kārbān

Kaāfir itmez itdügüñ hey nā-müselmānum benüm Ḥālüme raḥm itmedüñ raḥm itdi ḳāfìr müslümān

Merd iseñ nā-merd dünyāya zebūn olma zebūn

Ey Firāḳ̂̄ sen er og̉lısın ne 'avretdür cihān (Gıynaş 2017: 1985) 


\section{Gazel XIV}

Fâ'ilâtün/ Fâ'ilâtün/ Fâ'ilâtün/Fâ'ilün

Nev'-i āḩar der- baḥr-i mezbūr Ež-ān-i Firāḳ̄i Vā ị̣-Kütahiyyeli

Ḩāl-i cebheñ şāh-bāz ebrūlaruñdur bāl aña

Murg-i dil șayd olsa țañ mı ey hümā fi'l-ḥāl aña

Ṭopragium çāk ka'be-i kūyından alınmasa ger

Cān atup itmezdi dil bu resme isti 'cāl aña

Ş'ol gedādur kim nișāb-1 '1şḳdan alan nașīb

Salțanat gavàā vü gamdur devlet ü iḳbāl aña

Ben ölürsem ḥālümi arz eylesün tā ḥaşre dek

Sebze-i ḳabrüm zebān-1 ḥāl ile her sal aña

Tekye-i 'ālemde bir dervīş olaydı ger raḳīb

Ey Firāḳī ben hele dirdüm țoñuz abdāl aña (Gıynaş 2017: 248-249)

\section{Gazel XV}

Fâ'ilâtün/ Fâ'ilâtün/ Fâ'ilâtün/Fâ'ilün

Nev'i āhnar der- baḥr-i mezbūr Ež-ān-i Firāḳ̄ Vā iẓ-Kütahiyyeli

Gūş iden güftār-i yāri ḳān-i gevherden geçer

Nūş iden lā' 1 -i nigār-1 āb-1 Kevŝer'den geçer

Bir gümüş mengūşlı şarḳī sipāhi dil-berin

Sevse ger şāh-i cihān tāc-i mücevherden geçer

Degmesün müjgānlarum ruhsār-i yāra göz göre

Zaḩm irer ḩār-i siyeh gül-berg-i aḥmerden geçer

Nāvek-i āhum dil-i dil-dāra te 'ŝ̄r itmedi

Gerçi çerh oḳı gibi pūlād ü mermerden geçer

Halḳa-i zencīr-i hasretde Firāḳi mübtelā

Ş'ol ḳadar zār ü nizār oldı ki çenberden geçer (Gıynaş 2017: 917)

\section{Gazel XVI}

Mef'ûlü/ Fâ'ilâtü/ Mefâîlü/Fâ'ilün

Nev'-i dīger der-baḥr-i mef 'ūlü fā ilātü mefā '̄ilü fā' ilün Ež-ān-i Firāḳ̄ Vā' iz-Kütahiyyeli

Ey şāh̆-i şìve ġonçesi Bursa dil-āveri

Ref' it niḳābı gül gibi āfet gel e beri

Gelmezsin küsdi dime ki barışınca yār ${ }^{18}$

Olmazsa öp elin ayaġın öp al a beri

Tīhū-yi dil şikārına çeşmüñ havāle ḳıl

Şāhīnlerün bu cānibe yā hū șalā berī

Kol țoplamak günāhsa ḳul boynına eger

Boynuma șalınan günāhın efendi țola beri

Seyr eyle şehr-i Bursa'yı ag̉la sürūrla

Kūy-i visāl-i yārı Firāḳ̄ șula beri (Giynaş 2017: 2891-2892)

\footnotetext{
${ }^{18}$ Vezin kusurlu.
} 


\section{Gazel XVII}

Fâ'ilâtün/ Fâ'ilâtün/ Fâ'ilâtün/Fâ'ilün

\section{Naẓīre-i Firākī}

Dāg dāg üstine yaḳsun āteş-i ḥasret baña

Şah-1 'işḳam kim beneklü yaraşur hil' at baña

Ben ḳare günlü helāk olsam 'aceb mi gușșadan Gün yüzin göstermez oldı ol ḳamer-țal 'at baña

Pāyına düşdüm gezerken el șunup raḥm itmedi

Geçdi ‘ömrüm āh kim el virmedi devlet baña

La 1-i yārı dem-be-dem yād itdügümce ag̉laram

Geydürür ḳanlu yaşumdan la 'l-gūn hiil'at baña

Ey Firāḳ̂̄ buldug̉um sözi ögütsem țañ degül

Bir degirmendür bu 'ālem degdi çün nevbet baña (G1ynaş 2017: 159-160)

\section{Gazel XVIII}

Fe'ilâtün/ Fe'ilâtün/ Fe'ilâtün/ Fe'ilün

Naẓīre-i Firākī

Ey göñül bülbülüsin bir gül-i nāzük-bedenüñ

Yiridür ḩār-1 cefā üzre ḳ̂lursañ vațanuñ

Ne revā ben ayaguuñ öpimezin bād-1 șabā

Gire ḳoynına seḥer sen gül-i nāzük-bedenün

N'ola kan ag̉lar isem hiüzn ile Ya ḳūb-miŝal

Yaḳdı mihri beni sen Yūṣūf-1 gül- pīrehenüñ

Hūblar nāz ile șūfi bize kendüleri

Sevdürürler güçc ile ne șuçı vardur sevenüñ

Ger Firāḳ̄ kimün āluftesidür dirler ise

Cān u dilden senüñ ey şūh-1 sitem-kār senüñ (Köksal 2017: 906)

\section{Mütekerrir Murabba $\mathbf{I}^{19}$ \\ Mef'ûlü//Mefâ'îlü/Mefâ'îlü/Fe'ûlün \\ I \\ Dil șabr idemez sensüz eyā cān öleyin mi \\ Cān tende karāār itmedi bir ān öleyin mi \\ Göz göre behey āfet-i devrān öleyin mi \\ Sevdüm seni ey gözleri mestān öleyin mi}

II

Ey ġonca gülüm gülşenüm ey tāze bahārum

Bağruma ḳara dag̉lar uran lāle vü zārum

Aldurdum elümden çü șabā gibi ḳarārum

Sevdüm seni ey gözleri mestān [öleyin mi]

\footnotetext{
${ }^{19} \mathrm{Bkz} . \mathrm{Ek} 2$
} 


\section{III}

Dag̉larda gezüp șu gibi șahrāda yürürken

Sulțān olub[an] başuma tenhāca yürürken

Kul itdüñ efendi beni āzāde yürürken

Sevdüm seni ey gözleri mestān [öleyin mi]

IV

Ġurbetde kalup terk-i vațan mı edeyin ben

Āvāre başum ḳanda alayın gideyin ben

Hiç bilimezin n'eyleyeyin yā n'ideyin ben

Sevdüm seni ey gözleri mestān [öleyin mi]

V

Dil gonce-lebi ḳan-1la țolsun mı ne dirsin

Beñzüm șararup gül gibi solsun $m ı$ ne dirsin

Dir saña Firāḳi seven ölsün mi ne dirsin

Sevdüm seni ey gözleri mestān öleyin mi

\section{Firâkî’nin Yeni Şiirleri Üzerine Düşünceler}

Birinci gazel hezec bahri ile Eski Türk edebiyatı döneminin klâsik hayalleri kullanılarak yazılmıştır. Şiirde daha önce de belirtildiği üzere Firâkî, Türkçe kelimelere çokça yer vermiştir. Kan, kanı, şol, don, etmek, durmak gibi Türkçe kelimelerin ağırlığı şiirde görülmektedir. Şairin tespit edilen diğer şiirlerine de bakıldığında bu ifadeleri kullandığını görmek mümkündür.

Firâkî, çeviri yazısı verilen ikinci gazelinde bahr-i remel vezinlerinden birini kullanmıştır. Klâsik Türk şiirinin genel imgesi olan âşığın sevgili karşısındaki âciz durumu şiirde tasvir edilmiştir. Şiire bakıldığında diğer yayımlanan şiirleri gibi oldukça sade olduğu görülmektedir. Bu sadelik onun yaşadığı yüzyılda çok görülmemesine rağmen merkezden uzak bir hayat yaşadığından Arapça ve Farsça unsurlardan ziyade Eski Anadolu Türkçesinin özelliklerini görmek mümkündür.

Tespit ettiğimiz üçüncü gazel şiirler içerisinde Firâkî’nin diğerlerinden daha fazla Arapça ve Farsça unsurlar kullandığı şiirlerden biridir. Şiirde kullandığı deniz derya, bagrın taglamak, anası atası olmak, yakdı yandırdı sözcüklerinin bir arada kullanılması şiire âhenk katmıştır.

Son olarak, yer verilen musammat ise bahr-i hezec ile yazılmıştır. Şairin bu şiirinde de tıpkı diğer şiirlerinde olduğu gibi Anadolu Türkçesinin özelliklerini görmek mümkündür. Firâkî, bu anlamda şiirini Arapça ve Farsça unsurlarla doldurmamış, Türkçeye ait bazı kelimelere de yer vererek, son derece açık ve akıcı üslup elde etmeyi başarmıştır. "n'eylemek", "n'itmek” gibi örneklerini Eski Anadolu Türkçesi dönemi metinlerinde sıklıkla gördügümüz geçişme olayının kelimelerde görülmesi ile “edeyin”, "öleyin” gibi birinci şahıs ekinin kullanımı bu dönemin özelliklerini yansıtmaktadır. Verilen dizelerden birinde yer alan olub[an] da Firâkî'nin bu dönemin Türkçesi ile yazmasından dolayı tercih 
edildi. ${ }^{20}$ Yer yer halk şiiri gibi sade dil ile Eski Anadolu Türkçesi dönemine ait kelimelere yer veren şairin bu yönüyle XVI. yüzyıl şairleri arasında ayrı bir yere sahip olduğunu söylemek mümkündür.

Gerek bu çalışmada gerekse diğer çalışmalardaki yer alan Firâkî’nin şiirlerine bakıldığında şair, oldukça sade şiirler kaleme almıştır. Firâkî, fazla sayıda Türkçe kelime kullanmasına rağmen imale gibi aruz tasarruflarına çok gitmemiştir. Bu çalışmada yer verilen şiirlerin yalnızca beş mısrasında metin tamir yoluna başvuruldu. Bunlardan üçünün müstensihin hatası sonucu olduğu söylenebilir.

Pervane Bey mecmûasından alınan şiirlere bakıldığında da tercellî, dâr-1 dünya, iman, ışk-i mecâzî gibi tasavvufî terimleri sıklıkla kullandığını görülür. Bunun yanı sıra yeni tespit edilen şiirlerde Bursa ve Hicaz bölgeleri geçmektedir. Mecmûa sahipleri şiir başlıklarında şairin Kütahyalı ve vaiz oluşuna vurgu yapmıştır.

Şairin yayımlanan şiirlerine bakıldığında iki şehrin sıklıkla geçtiği görülür. Bunlar Bursa ve Kütahya'dır. Kütahya şairin Kütahyalı olmasından dolayı olduğunu söyleyebiliriz. Bursa şehri hem amcası Evliya Çelebi'yi hem de Firâkî'yi mest etmiştir. Evliya Çelebi, Seyahatnâme'sinde Firâkî ise gazellerinde bu şehrin adını zikreder. Evliya Çelebi ve Firâkî Çelebi’nin Bursa'ya bakışının benzerini Tanpınar'ın nesir ve şiirinde rastlamak mümkündür. ${ }^{21}$

Şair, âhenk unsurlarını oluşturabilmek için tekrarlardan yararlanmıştır. Örneğin on üçüncü gazeldeki el-eman ifadesi tekrarla oluşturulmuş bir âhenk unsurudur. Bunun dışında on üçüncü gazelin dördüncü beyitinde geçen "zebun olma zebun” ifadesi de şiire âhenk katan ifadedir. Yine şairin pepeli gazel gibi âhenk unsurunun ön planda olduğu şiiri de vardır. ${ }^{22}$ Şairin nûş iden ve gûş̧ iden ifadelerini bir mısrada alt alta vermesi de bunun sonucudur. Şâirin mütekerrir murabba şeklini kullanmayı tercih etmesi de âhenk oluşturma isteğiyle bağdaştırılabilir.

Şairin şiirlerinde yer alan kafiye ve rediflere baktığımızda da bazı sonuçlar elde etmek mümkündür. Şairin genellikle tam kafiye kullandığını ve rediflerde ise var, değil, ana, -den geçer gibi tam bir redife sahip olan şiirler kaleme aldığg görülür.

XVI. yüzy1l şairlerinin çoğunlukla Fâ'ilâtün/Fâ'ilâtün/Fâ'ilâtün/Fâ'ilün veznini tercih ettiği görülür (Flemming 1994: 64). Her ne kadar dîvânı tespit edilemeyen şair için vezinlerin istatistiksel verilerini vermek uygun olmasa da Firâkî Çelebî de XVI. yüzyıl şairlerinin en çok tercih ettiği bu kalıbı şiirde sıklıkla kullanmıştır. Firâkî Çelebî’nin tespit edilen aruz kalıpları ve bu kalıpların kullanım sıklığı şu şekildedir. ${ }^{23}$

\footnotetext{
${ }^{20}$ Eski Anadolu Türkçesi’nde kullanılan ekler ve ses olayları hakkında ayrıntılı bilgi için bkz. Şahin 2011

${ }^{21}$ bkz. Tanpınar 2011: 97-119; Tanpınar 2015: 52

${ }^{22} \mathrm{Bu}$ şiirler için bkz. Güler 2016: 87

${ }^{23} \mathrm{Bu}$ çalışmada yararlandığımız kaynaklarda yer alan tüm şiirlerin aruzları dahil edilmiştir.
} 
Tablo 1: Firâkî Çelebi’nin Yayımlanan Şiirlerindeki Vezin Kullanım Sıklığı

\begin{tabular}{|l|l|l|}
\hline $\begin{array}{l}\text { Satır } \\
\text { No. }\end{array}$ & Vezin & $\begin{array}{l}\text { Kullanım } \\
\text { Sıklığı }\end{array}$ \\
\hline 1 & Fâ'ilâtün/ Fâ'ilâtün/ Fâ'ilâtün/ Fâ'ilün & 26 \\
\hline 2 & Fe'ilâtün/ Fe'ilâtün/ Fe'ilâtün/ Fe'ilün & 8 \\
\hline 3 & Mefâ'ilün/ Mefâ'ilün/ Mefâ'ilün/ Mefâ'ilün & 11 \\
\hline 4 & Mefâ'ilün/ Fe'ilâtün/Mefâ'lün/ Fe'ilün & 1 \\
\hline 5 & Mef'ûlü/ Mefâ'ilü/ Mefâ'ilü/ Fe'ûlün & 4 \\
\hline 6 & Fe'ilâtün/ Mefâ'ilün/ Fe'ilün & 3 \\
\hline 7 & Mefâ'̂lün/ Mefâ'îlün/ Fe'ûlün & 4 \\
\hline 8 & Fâ'ilâtün/ Fâ'ilâtün/ Fâ'ilün & 1 \\
\hline 9 & Mefâ'îlün/ Mefâ'îlün/ Feilün & 1 \\
\hline 10 & Mef'ûlü/ Fâ'ilâtü/ Mefâilü/ Fâ'ilün & 1 \\
\hline 11 & Mef'ûlü/ Fâ'ilâtün/ Mef'ûlü/ Fâ'ilâtün & 2 \\
\hline
\end{tabular}

Tabloda da görüldüğü üzere Firâkî’nin bugüne kadar altmış iki şiiri gün yüzüne çıkarılmıştır. Bugüne kadar çıkarılan şiirlerde şairin on bir farklı aruz ölçüsüyle şiirler yazdığı tespit edilmiştir. Türk şairlerinin ortalama olarak on beş farklı aruz kalıbı ile şiir yazdığını düşündüğümüzde şairin dîvânı bulunduğu takdirde farklı aruz ölçüleriyle şiirler yazmış olduğunu göreceğimiz muhtemeldir.

\section{Sonuç}

XVI. yüzyıl şairlerinden Firâkî, kendi çağının nevi şahsına münhasır şairlerinden biridir. Evliya Çelebi'nin amcası olarak kayıtlara geçen şair, çoğu şair gibi âhenk unsurlarını son derece etkili kullanmıştır. Çalışmalar neticesinde ona ait eserler gün yüzüne çıkarıldıysa da dîvânına henüz rastlanılamamıştır. Şiir söyleme kabiliyetine bakıldığında onun şiir ve edebiyat bilgisine son derece vâkıf olduğu görülmektedir. Şiirleri bugüne değin mecmuaların arasında kalmış ve araştırmacıların mecmualar hakkındaki çalışmaları sonucunda gün yüzüne çıkmıştır.

Dîvânı tespit edilemeyen şairlerin sanatı hakkında birtakım değerlendirmelerde bulunabilmek için mecmualar son derece önemlidir. Firâkî'nin şiir ve sanat hayatı hakkında birtakım fikirleri söyleyebilmek için de mecmualardan faydalanılmıştır. Yurt içindeki kütüphanelerde bulunan Firâkî’ye ait şiirler, tespit edilip araştırmacılar tarafından yayımlanmıştır. Fakat genel olarak yurt dışındaki kaynaklar ihmal edilmiştir. Özellikle sosyal bilimler üzerine yapılacak olan çalışmalarda literatür taraması yaparken yurt dışı kaynaklarına da bakılması gerekmektedir. Bu sebeple çalışmada gerek yurt içindeki gerekse yurt dışındaki mecmualardan tespit edilen şiirlere yer verilmiştir. Böylece yurt içindeki 
kaynakların yanı sıra yurt dışındaki kaynakların da araştırmacılar tarafından kullanılması gerektiğine dikkat çekilmiş̧tir.

Bu çalışmada yurtiçi ve yurtdışında bulunan kütüphanelerdeki mecmûlardan Firâkî’ye ait üçü gazel biri mütekerrir murabba olmak üzere toplam dört şiir tespit edilmiştir. Bunlardan yurt dişındaki kütüphanelerden tespit edilen iki şiir bulunmaktadır. Paris National Bibliotuge'te bir gazel ve bir murabba, Süleymaniye Yazma Eserler Kütüphanesi'nde ise çeşitli mecmualardan ikisi gazel bir terci-i bend olmak üzere üç şiiri tespit edilmiştir. Tespit edilen bu üç şiirden birinin daha önce yayımlanmış olması dolayısıyla sadece müstensihin şiirin nazım şeklini yanlış yazdığına değinildi. Ayrıca daha önce yayımlanan şiirde nüshanın silik olmasından dolayı okunamayan beyit, tarafımızdan tespit edilen nüshadan okunup beytin tamamlanmasiyla yetinildi.

Ayrıca Pervâne Bey mecmûasında yer alan on dört şiir ile daha önce yayımlanmamış Mecmûa'u'n-nezâir'deki bir şiir çalışmaya dahil edildi. Firâkî'nin sanat anlayışını ortaya koymak için önemli olan ve tarafımızdan tespit edilen on dokuz şiir çeviriyazı biçiminde verildi. Bu şiirler hakkında genel bir değerlendirilme yapıldı.

Yurt dışındaki kaynakların bir kısmına ulaşılamamakla birlikte bunları yazmalar genel ağında bulmak mümkündür. Dipnotta verilen ülkelerdeki ulaşamadığımız yazmalar konusunda uğraşımız devam etmekte olup buradaki yazmalar elde edildiği takdirde bir başka çalışmada konu edinmeyi amaçlamaktayız.

Tespit edilen şiirler günümüz harflerine aktarılarak bilim dünyasına tanıtılmıştır. Çalışmada şaire dair bilgi verilmesinin ardından şair hakkında bu zamana kadar yapılan çalışmalardan bahsedilmiştir. Taramalar sonucunda Firâkî'ye ait on beş çalışma tespit edilmiştir. Bu çalışmalar daha çok Firâkî̀ye ait olan eserlerin latin harflerine aktarımı ile mecmualar arasında kalan şiirlerin yayımlarını kapsamaktadır. Firâkî’nin mecmualardaki şiirlerinin tespit edilip yayımlanması Firâkî hakkında başka çıkarımlar yapılmasına olanak sağlayacaktır.

Şiirler üzerine tespitler yapılarak şairin genel üslûbu hakkında değerlendirmelerde bulunuldu. Yeni şiirler üzerinden yapılan değerlendirmeler sonucunda Firâkî’nin yaşadığı yüzyıl olan XVI. yüzyıl içerisinde diğer şairlere kıyasla dilinin son derece sade, yer yer halk şiirine yakın söyleyişlere sahip olduğu ve bununla birlikte şiirlerinde Eski Anadolu Türkçesi dönemine ait pek çok kelimeyi barındırdığı tespit edildi. Firâkî, şiirinde bağrın dağlamak, kan etmek, deniz derya, şol, el bağlamak, taşmak gibi Türkçe ifadelere sıklıkla yer verdiğine değinildi. Firâkî’nin Arapça ve Farsça etkisinden uzak, Türkçe ifadelere şiirinde sıklıkla yer vermesinin sebebi şairin İstanbul'dan uzak bir hayat yaşamasına bağlanabilir.

Abdurrahman Çelebi, şu ana kadar tespit edilen altmış iki şiirinde toplam on bir farklı aruz kalıbı kullanmıştır. Bunlardan yirmi altı tanesi aruzun Fâ'ilâtün/ Fâ'ilâtün/ Fâ'ilâtün/ Fâ'ilün kalıbıdır. Bu 
kalıp XVI. yüzyılın en çok tercih edilen kalıplarından birisidir. Her ne kadar dîvânı henüz bulunamasa da yayımlanan şiirlerinden hareketle Firâkî Abdurrahman Çelebi de bu tercihe uyduğu görülmüştür.

Diğer araştırmacıların ve tezkire sahiplerinin Firâkî’nin şiirlerinden örnek verdiği kısımlara bakıldığında şairin kaside, murabba, gazel, matla, müfred gibi çok farklı şekillerde şiir yazdığı görülür. Firâkî hakkında yapılan çalışmalara bakıldığında onun şiir yönünün çok kuvvetli olduğu görüşü söylenebildiği gibi şairin nesir yönünün de son derece iyi olduğu söylenebilir.

Firâkî hakkında yapılan çalışmalara bakıldığında gün yüzüne çıkan eserlerinin tamamı çeviri yazıya aktarıldığg görülür. Evliya Çelebi, Seyahatnâme'sinde Firâkî Çelebî’nin kırk üç eseri olduğunu belirtmesi sebebiyle çevrilen eserlere bakıldığında bugüne kadar tespit edilenlerin aslında sınırlı sayıda olduğunu söylemek mümkündür. Araştırmacıların Türkiye ve dünyada bulunan kütüphanelerdeki yazma eserler üzerinde çalışmaları sonucunda Firâkî’nin başta dîvânı olmak üzere pek çok risale ve başka türden eserlerinin ortaya çıkaracağına inanmaktayız.

\section{Kaynaklar}

Avçin, Mehmet (2011) Terceme-i Ahlâk-ı Muhsînî (1b-99a) İnceleme-Metin, Yüksek Lisans Tezi, Dumlupınar Üniversitesi, Kütahya.

Bayram, Asuman (2017a) Firâkî Hüsrev ü Şîrîn, http://ekitap.kulturturizm.gov.tr/Eklenti/55736,husrev-usirinpdf.pdf?0 (E.T.: 22.07.2018)

Bayram, Asuman (2017b) Firâkî̀nin Hüsrev ü Şîîn'i İnceleme- Metin- Bağlamlı Dizin ve İşlevsel Sözlük, Yüksek Lisans Tezi, Hacettepe Üniversitesi, Ankara.

Bibliothègue nationale de France, Département des manuscrits, Turc 288, yk. 5 b.

Bibliothègue nationale de France, Département des manuscrits, Turc 302, yk. 22b.

Çelik, Halit (2011) Se'âdetnâme İnceleme-Metin, Yüksek Lisans Tezi, Dumlupınar Üniversitesi, Kütahya.

Dağlı, Yücel vd. (2005) Evliya Çelebi Seyahatnâmesi, Cilt: 9, İstanbul: Yapı Kredi Yayınları.

Er, Şaban (2013) Se'âdetnâme, İstanbul: Kutup Yıldızı Yayınları.

Ersoy, Ersen (2003) XVI. Yüzyll Kaynaklarına Göre Kütahyalı Şairler ve Kütahya'da Edebî Muhît, Dumlupınar Üniversitesi, Yüksek Lisans Tezi, Dumlupınar Üniversitesi, Kütahya.

Ersoylu, Halil (1995) “Kaside-i Kalem”, Türk Dili Araştırmaları Yıllı̆̆ı Belleten 1992, 147-167.

Flemming, Barbara (1994) "Notes On Arûz in Turkish Cellections", Arabic Prosody And It's Applications in Muslim Poetry, Swedish Research Institute in Istanbul, Uppsala.

Gıynaş, Kâmil Ali (2017) Pervâne Bey Mecmuası, Kültür Turizm Bakanlığı yayınları, e-kitap, http://ekitap.kulturturizm.gov.tr/Eklenti/55832,pervane-bey-mecmuasi-pdf.pdf?0 , (E.T.: 25. 07. 2018)

Güler, Kadir (2004) Kütahya Yazıları, Ankara: Bizim Büro Basımevi Yayınları.

Güler, Kadir (2010a) Kütahya Şâirleri I, Kütahya: Kütahya Valiliği Yayınları

Güler, Kadir (2010b) "Kütahyalı Firâkî ve Bilinmeyen Şiirleri", Turkish Studies International Periodical For the Languages, Literature and History of Turkish or Turkic 5 (1), ss. 1037-1066.

Güler, Kadir (2016) Kütahya'nın Sirları, Kütahya: Ekspres Matbaası.

Güler, Kadir (2017) Kütahya Şairleri, Kütahya: Ekspres Matbaası.

Güner, Hamza (1967) Başlangıcından Zamanımıza Kadar Kütahyalı Şairler, Kütahya: Kütahya İl Basımevi.

Kalpaklı, Mehmet (1997) “Bir Kasidenin Yayımı Dolayısıla”, Toplumsal Tarih Dergisi, Cilt: 8, Sayı: 47, 38. 
Kocatürk, Vasfi Mahir (1963) Dîvân Şiiri Antolojisi, İstanbul: Edebiyat Yayınevi.

Köksal Mehmet Fatih (2013) "Firâkî"

http://www.turkedebiyatiisimlersozlugu.com/index.php?sayfa=detay\&detay=375 [Erişim Tarihi: 20. 07. 2018]

Köksal, Mehmet Fatih (2017) Mecma'u’n Nezâir, Kültür Turizm Bakanlığı yayınları, e-kitap, http://ekitap.kulturturizm.gov.tr/Eklenti/56057,mecmaun-nezair-edirneli-nazmi-pdf.pdf?0 [Erişim Tarihi: 25. 07. 2018]

Kutluk, İbrahim (1997) Beyâni Mustafa Bin Carullah, Tezkiretü’ş - Şuarâ, Ankara: Türk Tarih Kurumu Yayınları.

Mecmûa-i Eş'âr, Süleymaniye Yazma Eserler Kütüphanesi, Ali Nihat Tarlan Koleksiyonu, 59/1, yk. 22a-22b.

Memûa-i Eş'âr, Süleymaniye Yazma Eserler Kütüphanesi, Tercüman Gazetesi Kütüphanesi Koleksiyonu, Y-110, yk. 20a.

Mutlu, Merve (2014) “Süleymaniye Kütüphanesi Nuri Arlasez Koleksiyonu 263 Numarada Mecmû 'atü'l-Eş'âr Adıyla Kayıtlı Şiirler Mecmuası ve Firâkî’ye Ait Şiirler”, Türük Uluslararası Dil, Edebiyat ve Halkbilimi Araştırmaları Dergisi, Cilt: 1, Sayı: 3, 112-122.

Önen, Yücel (2009) Kırk Su'al İnceleme- Metin- Sözlük, Yüksek Lisans Tezi, Dumlupınar Üniversitesi, Kütahya. Süleymaniye Yazma Eserler Kütüphanesi, Nuruosmaniye Koleksiyonu, 04959-004 arşiv numaralı eser, yk. 373b. Şahin, Hatice (2011) Eski Anadolu Türkçesi, Ankara: Akçă̆ Yayınları.

Tanpınar, Ahmet Hamdi (2015) Bütün Şiirleri, İstanbul: Dergâh Yayınları.

Tanpınar, Ahmet Hamdi (2011) Beş Şehir, İstanbul: Dergâh Yayınları. 


\section{Ekler}

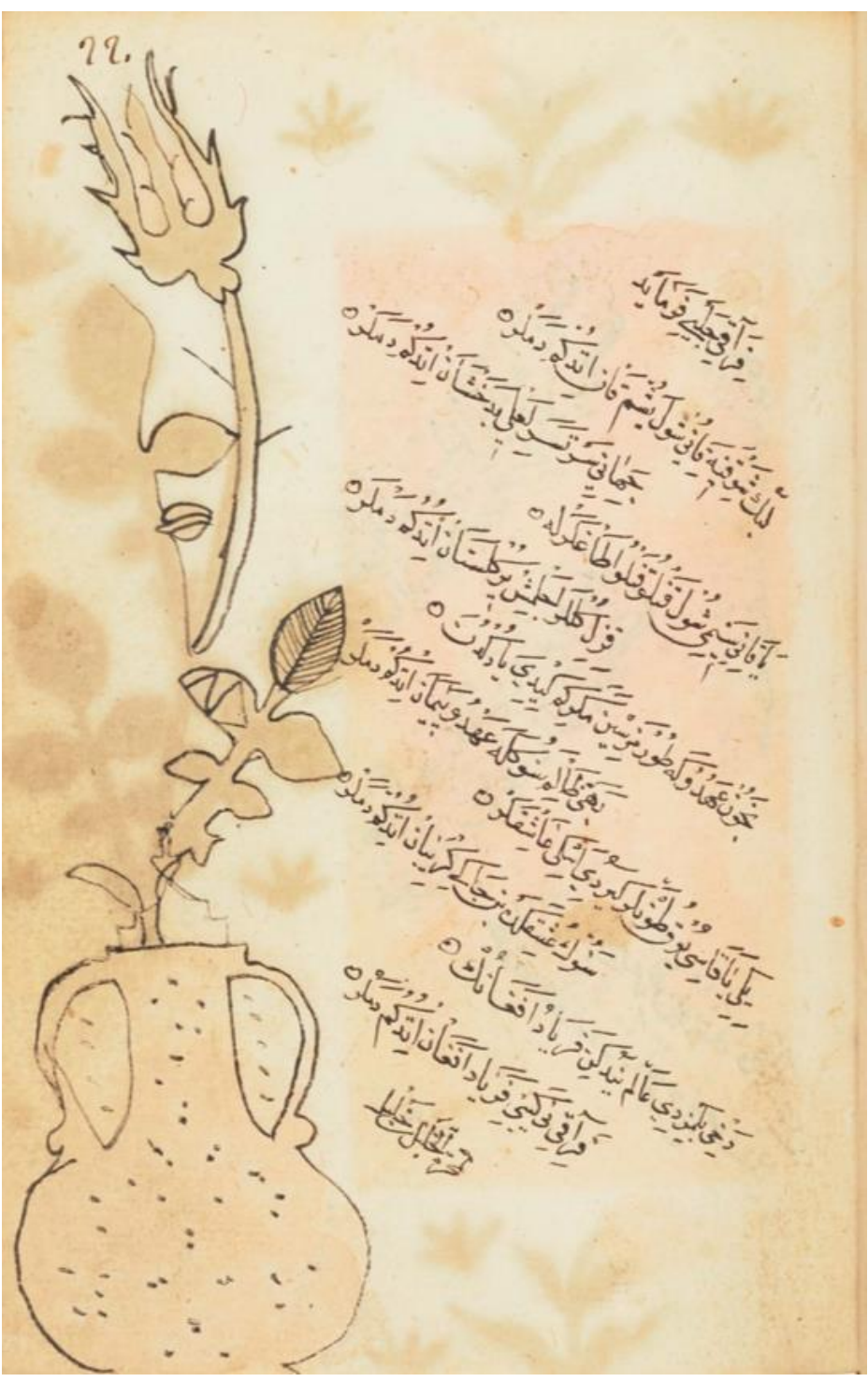

Ek: 1 Bibliothègue nationale de France, Département des manuscrits, Turc 302 yk. 22b 


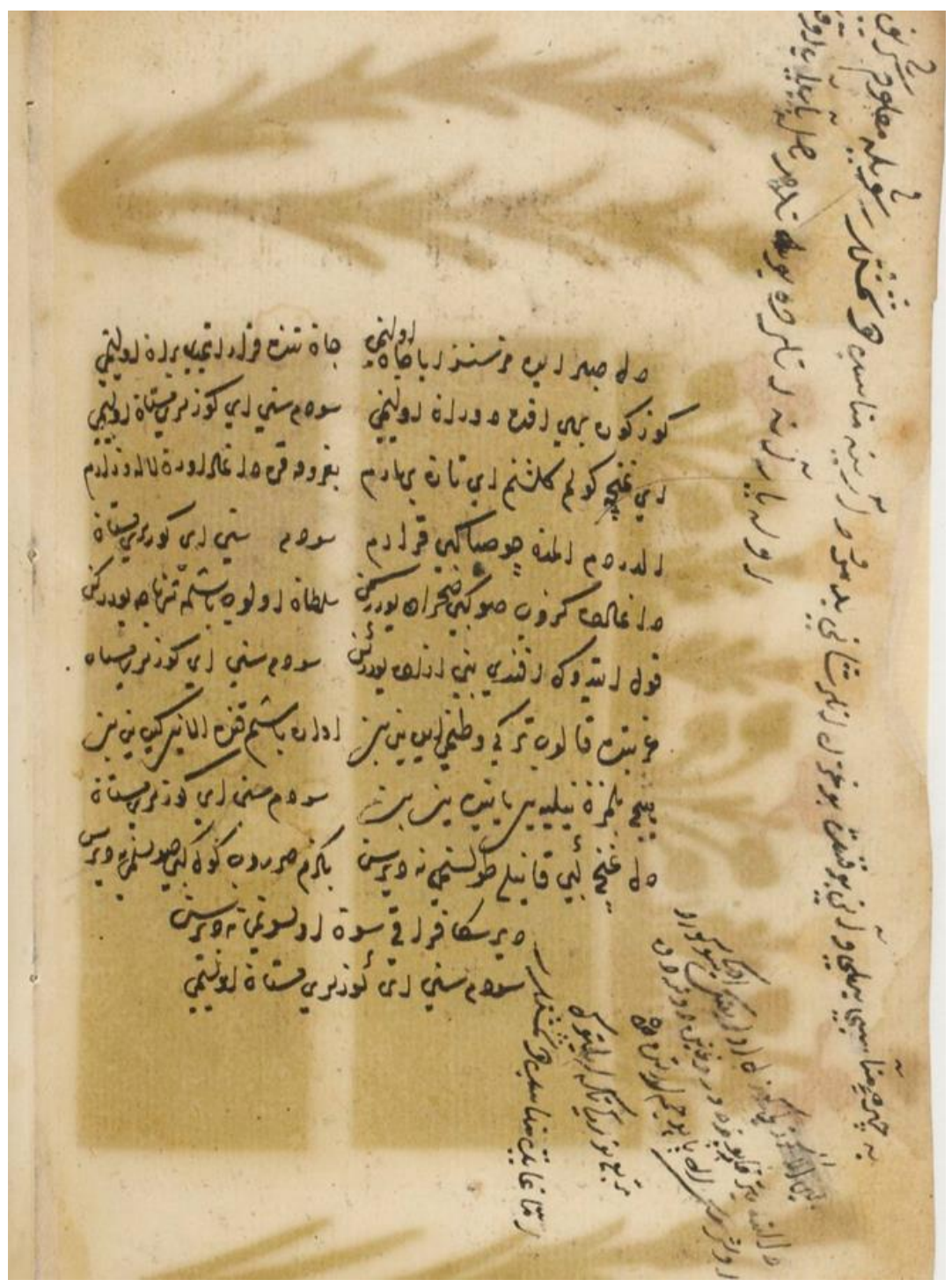

Ek: 2 Bibliothègue nationale de France, Département des manuscrits, Turc 288 yk. 5b 


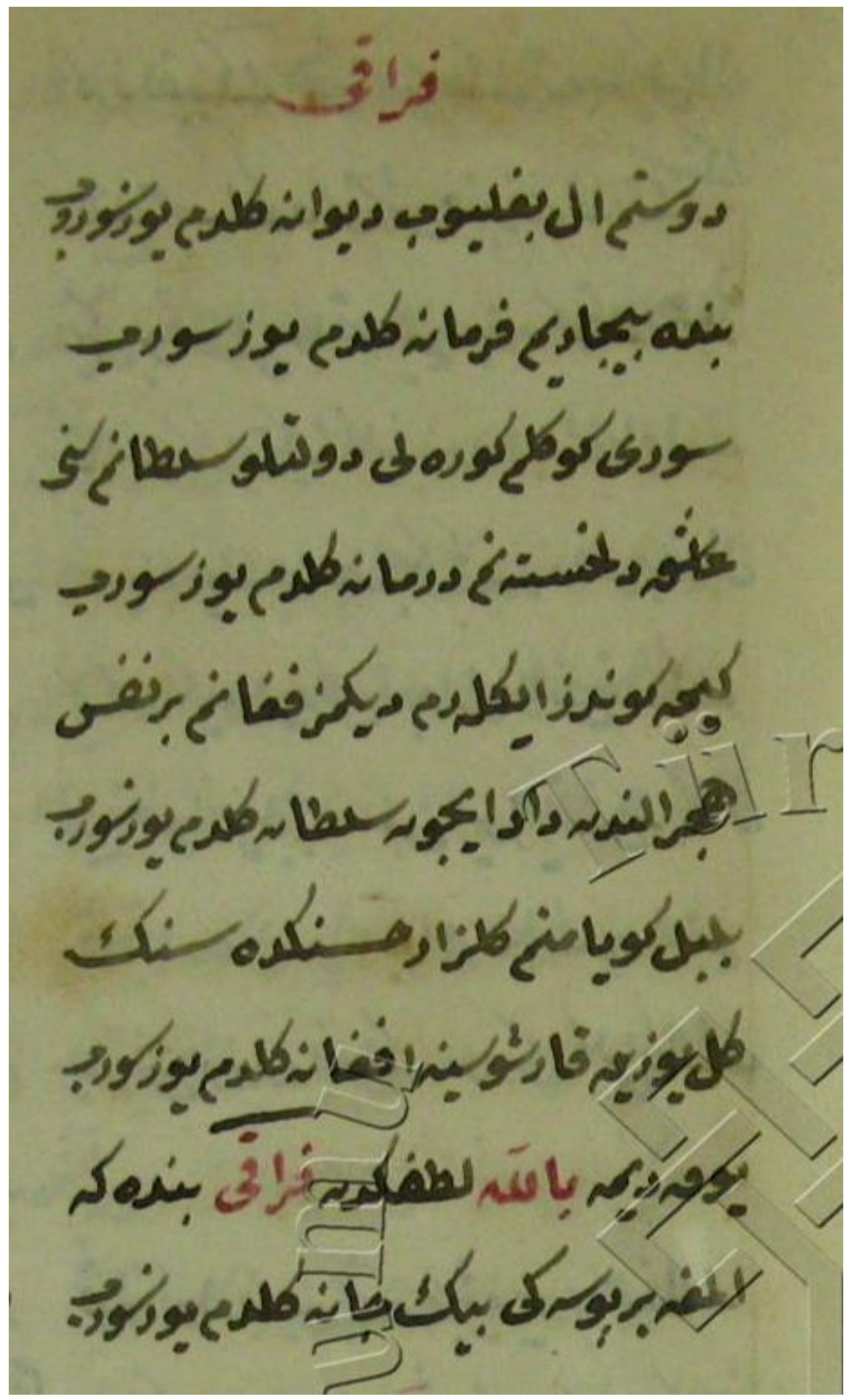

Ek: 3 Süleymaniye Yazma Eserler Kütüphanesi Tercüman Gazetesi Kütüphanesi Türkçe Yazmalar Bölümü Y110 Arşiv numaralı Mecmu'â-i Eş'âr isimli yazma yk. 20a 


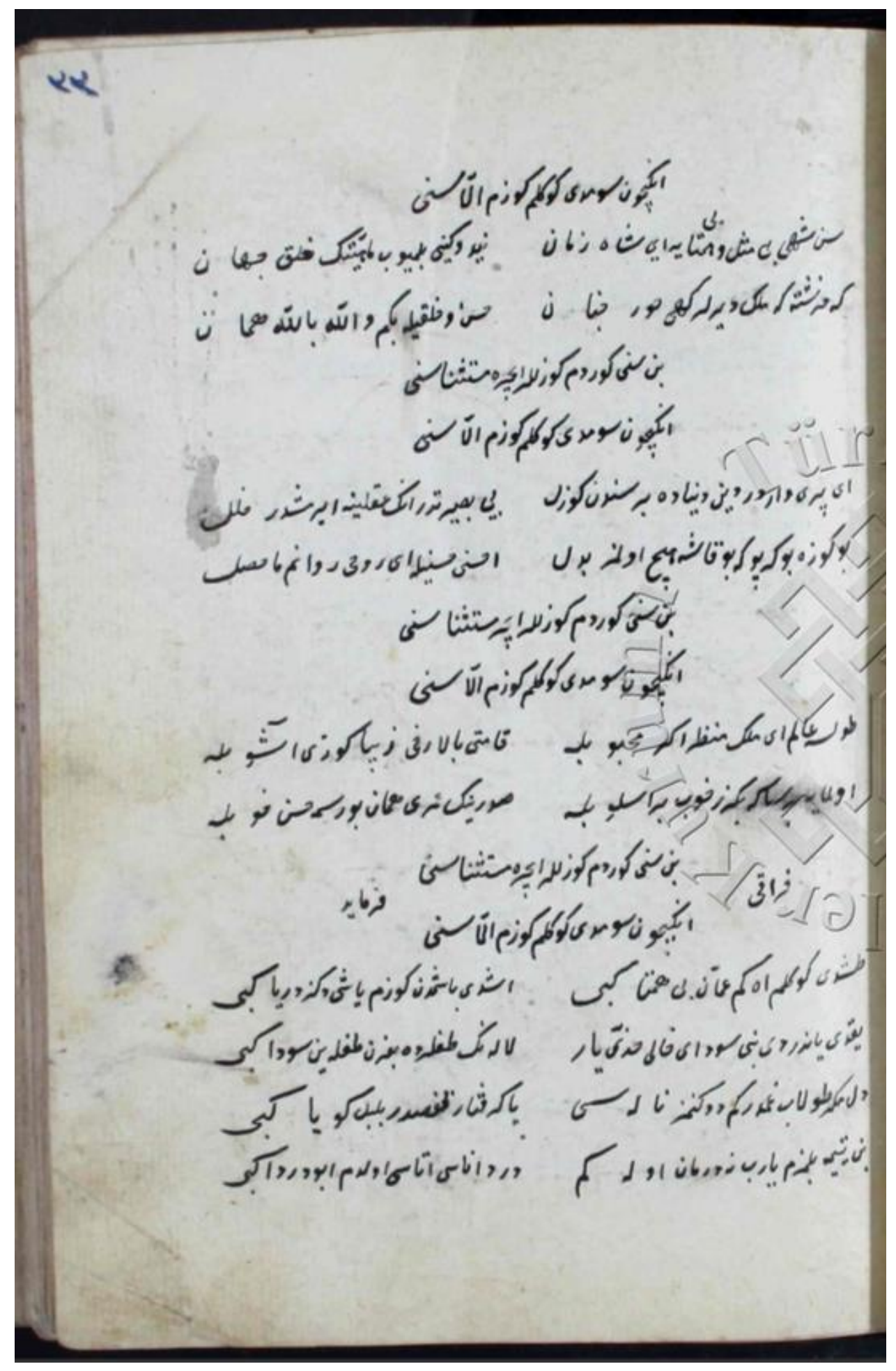

Ek: 4 Süleymaniye Kütüphanesi Ali Nihat Tarlan Koleksiyonu Mecmuâ-i Eş’âr 59/1 arşiv numaralı yk. 22a 


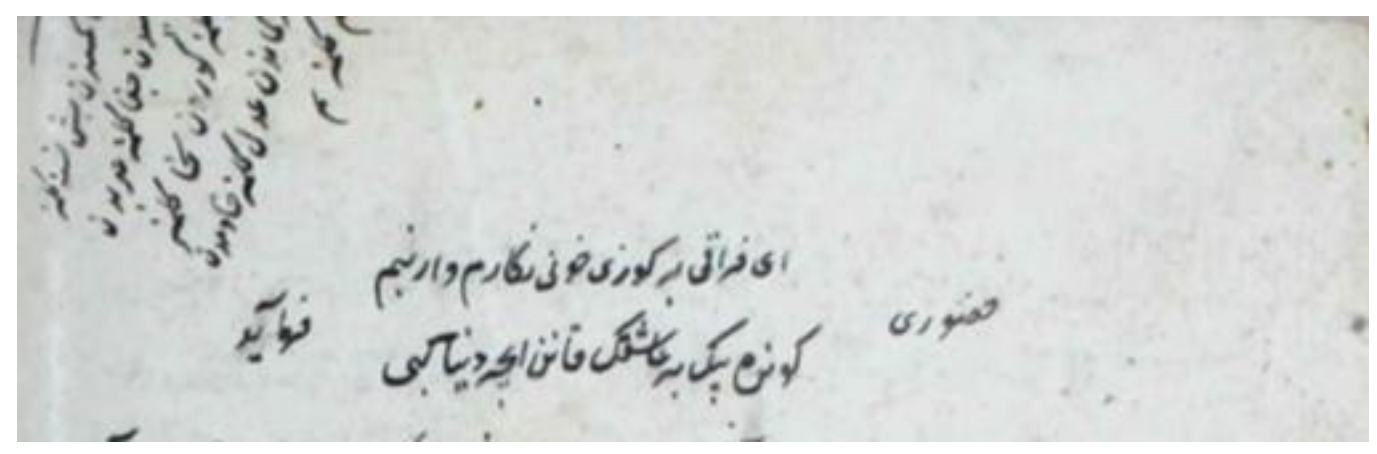

Ek 5: Süleymaniye Kütüphanesi Ali Nihat Tarlan Koleksiyonu Mecmuâ-i Eş’âr 59/1 arşiv numaralı yk. 22b

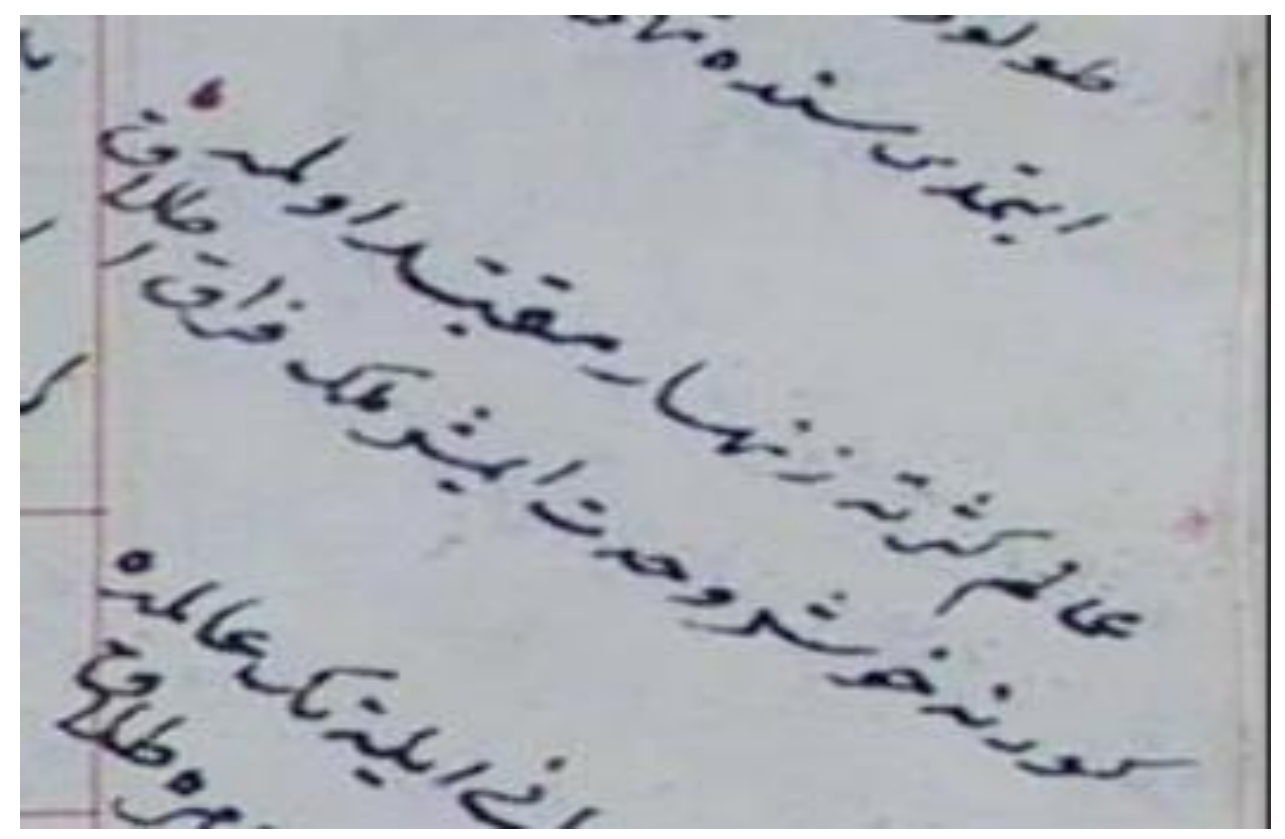

Ek 6: Süleymaniye Kütüphanesi Nuruosmaniye Koleksiyonu 04959-004 arşiv numaralı yk. 373b (sayfa kenarı) 